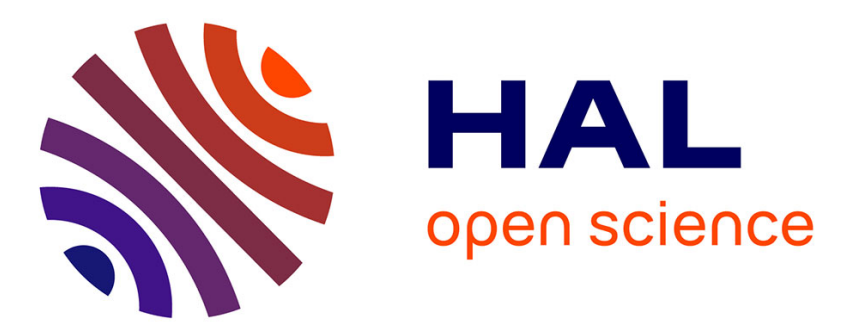

\title{
Absence of direct regulation of prolactin cells by estradiol 17- $\beta$ in rainbow trout (Oncorhynchus mykiss)
}

Pascale Le Goff, G. Salbert, Patrick Prunet, Christian Saligaut, B. Bjornsson, C. Haux, Y. Valotaire

\section{- To cite this version:}

Pascale Le Goff, G. Salbert, Patrick Prunet, Christian Saligaut, B. Bjornsson, et al.. Absence of direct regulation of prolactin cells by estradiol $17-\beta$ in rainbow trout (Oncorhynchus mykiss). Molecular and Cellular Endocrinology, 1992, 90, pp.133-139. hal-02712815

\section{HAL Id: hal-02712815 \\ https://hal.inrae.fr/hal-02712815}

Submitted on 1 Jun 2020

HAL is a multi-disciplinary open access archive for the deposit and dissemination of scientific research documents, whether they are published or not. The documents may come from teaching and research institutions in France or abroad, or from public or private research centers.
L'archive ouverte pluridisciplinaire HAL, est destinée au dépôt et à la diffusion de documents scientifiques de niveau recherche, publiés ou non, émanant des établissements d'enseignement et de recherche français ou étrangers, des laboratoires publics ou privés. 


\title{
Absence of direct regulation of prolactin cells by estradiol-17 $\beta$ in rainbow trout (Oncorhynchus mykiss)
}

\author{
P. Le Goff ${ }^{a, b}$, G. Salbert ${ }^{\text {c }}$, P. Prunet ${ }^{\text {b }}$, C. Saligaut ${ }^{c}$, B.Th. Bjornsson ${ }^{\text {d }}$, C. Haux ${ }^{\text {d }}$ \\ and $\mathbf{Y}$. Valotaire ${ }^{a}$ \\ ${ }^{a}$ Laboratoire de Biologie Moléculaire, U.R.A. 256 C.N.R.S., Université de Rennes 1, 35042 Rennes, France, ${ }^{b}$ Laboratoire de Physiologie des Poissons, \\ I.N.R.A., Campus de Beaulieu, 35042 Rennes, France, ${ }^{c}$ Laboratoire de Physiologie des Régulations, U.R.A. 256 C.N.R.S., Université de Rennes I, \\ 35042 Rennes, France, and ${ }^{d}$ Department of Zoophysiology, University of Göteborg, 40031 Göteborg, Sweden
}

(Received 29 July 1992; accepted 2 September 1992)

Key words: Prolactin; Regulation; 17 $\beta$-Estradiol; Estradiol receptor; (Rainbow trout)

\section{Summary}

The effects of estradiol-17 $\left(\mathrm{E}_{2}\right)$ implants on plasma prolactin (PRL) concentrations, pituitary PRL content and pituitary PRL mRNA levels were examined in rainbow trout (Oncorhynchus mykiss). Intact immature fish treated with $1 \mathrm{mg}$ estradiol-17 $\beta$ did not show significant changes in both PRL mRNA levels and pituitary PRL content after 3 days of treatment. In a similar experiment, no changes were observed in plasma PRL levels followed during 7 days. Similarly, lack of estradiol-17 $\beta$ effect on plasma PRL levels and on final PRL pituitary content was observed in ovariectomized female rainbow trout treated during 48 days with $25 \mathrm{mg}$ estradiol-17 $\beta$ and in mature male fish over a 3-week treatment period. Localization of estradiol receptor (ER) mRNAs in the pituitary was carried out by Northern blot analysis using a full-length rainbow trout estrogen receptor (rtER) cDNA as a probe. The rostral pars distalis of the pituitary which contained mostly PRL cells showed the lower amount of rtER mRNA when compared to other parts of the pituitary. Moreover, two mRNAs of different size (3.5 and $1.4 \mathrm{~kb})$ were detected in different parts of the pituitary. Further hybridization experiments using probes containing part of the rtER cDNA (E domain or $\mathrm{C}$ and $\mathrm{D}$ domains) indicated that the small-sized mRNA $(1.4 \mathrm{~kb})$ probably encodes a truncated ER protein lacking hormone binding domain or an ER-related protein. Thus, only the $3.56 \mathrm{~kb}$ mRNA appeared to be involved in the regulation of pituitary function by estradiol. In situ hybridization analysis allowed a more precise localization of this rtER mRNA in the pituitary. No labeling was discernible over PRL cells whereas other parts of the pituitary were labeled. Grain counting corroborated this localization. These results indicate that (1) in vivo estradiol-17 $\beta$ treatment did not modify PRL cell activity in rainbow trout, (2) PRL secretion, in this fish species, is not directly regulated by estradiol.

\section{Introduction}

It has long been shown that estrogens play an important role in the control of prolactin (PRL) secretion in mammals and are able to stimulate circulating PRL concentrations (Chen and Meites, 1970; Kalra et al., 1973; Shin et al., 1974). However, their mechanisms of action are still debated. $17 \beta$-Estradiol $\left(\mathrm{E}_{2}\right)$ stimulates PRL sccretion by a direct action on pituitary cells in

Correspondence to: P. Prunet, Laboratoire de Physiologie des Poissons, I.N.R.A., Campus de Beaulieu, 35042 Rennes Cedex, France. which it both enhances PRL mRNA production dramatically and increases the mitotic activity of PRL cells (Lieberman et al., 1982; Takahashi and Kawashima, 1987). Moreover, in vitro studies suggest that the direct effect of $E_{2}$ on PRL cells could be exerted by two other mechanisms: an increase in their sensitivity to thyrotropin-releasing hormone (TRH), one of the most potent PRL-releasing factors (PRF), and a decrease in their sensitivity to dopamine, considered as the most likely PRL-inhibiting factor (De Lean et al., 1977; Pasqualini et al., 1986; Zhang et al., 1990). Further in vivo studies also indicate that estrogens not only act directly on the lactotrophs but also modulate activity of the central system which controls PRL pituitary release 
(Fink, 1988). An acute effect of $E_{2}$ on PRL release and on PRL cell recruitment has also been demonstrated in the rat via releasc of a PRF from the hypophyseal neurointermediate lobe (Ellerkmann et al., 1991).

Although much less developed, available information on teleost fish suggests that estrogens may also regulate PRL cell activity. $E_{2}$ stimulates $P R L$ synthesis in tilapia (Wigham et al., 1977) and markely activates PRL cells in mudsucker and in eel (Nagahama et al., 1975; Olivereau and Olivereau, 1979; Olivereau et al., 1986). In vitro studies using organ-cultured pituitary from tilapia also indicate that estradiol treatment both stimulates spontaneous PRL release when tested in a hyperosmotic environment and promotes stimulation of PRL release by TRH (Barry and Grau, 1986). However, recent studies in rainbow trout indicate that, in this fish species, plasma PRL levels do not significantly change during vitellogenesis when large increases in plasma estradiol levels are observed (Prunet, P., Bjornsson, B.Th. and Haux, C., unpublished data). This suggests a different control of PRL secretion by estrogen to what has been described in other fish or mammals.

In order to further confirm such absence of control by estrogen, we have been investigating effects of in vivo estradiol treatment on PRL cell activity in both mature and immature fish. This was completed by localization of estradiol receptor (ER) in the pituitary, in particular with regard to PRL cells which are located in the rostral part of the adenohypophysis. Using a cDNA probe coding for rainbow trout estradiol receptor (rtER) (Pakdel et al., 1989), Northern blot and in situ hybridization analyses of different parts of the pituitary were performed.

\section{Materials and methods}

\section{Animals}

Rainbow trout (Oncorhynchus mykiss) of both sexes at different maturity stages werc brought to the laboratory and kept in tanks supplied with recirculating tap water under a natural photoperiod and at a temperature of $13-15^{\circ} \mathrm{C}$.

\section{Estradiol treatment}

Experiment 1. Immature rainbow trout of both sexes with a mean body weight of about $100 \mathrm{~g}$ were injected intraperitoneally with $\mathrm{E}_{2}$ (Sigma, 1 or $10 \mu \mathrm{g} / \mathrm{g}$ body weight) dissolved in absolute ethanol and suspended in cacao butter. Control fish were injected with solvent. Blood was collected by caudal puncturc 1,3 and 7 days later for plasma PRL and $\mathrm{E}_{2}$ level measurements.

Experiment 2. Immature rainbow trout (with a mean body weight of $140 \mathrm{~g}$ ) were treated with $\mathrm{E}_{2}$ (5 $\mu \mathrm{g} / \mathrm{g}$ body weight) as in experiment 1 and pituitaries were collected after 3 days of treatment for PRL and PRL mRNA measurements.

Experiment 3. Adult rainbow trout (mature males) were treated with estradiol (silastic implants in the intraperitoneal cavity) at different doses $(0,0.5,5 \mu \mathrm{g} / \mathrm{g}$ body weight). Blood was collected on days $4,7,15$ and 21 after application of the treatment for plasma PRI. measurements. Pituitaries were collected after 3 weeks of treatment for PRL content measurements.

Experiment 4. Mature female rainbow trout weighing about $1.5 \mathrm{~kg}$ (summer-spawning strain; ovarian recrudescence; gonadosomatic index lower than $1 \%$ ) were ovariectomized. Sham surgery and ovariectomy were performed according to Bommelaer et al. (1981). Ovariectomized fish of the $E_{2}$ group received an implant of cstradiol ( $25 \mathrm{mg} \mathrm{E}_{2} /$ implant prepared by Organon Laboratories, UK). Blood samples were taken before surgery and then on days 21,35 and 48 . On day 49 , the fish were killed by decapitation and pituitaries were collected for PRL content measurement.

\section{Radioimmunoassays}

Pituitary and plasma PRL levels were determined using a specific radioimmunoassay (RIA) for salmonid PRL (Prunet et al., 1985).

Plasma $E_{2}$ levels were determined by RIA as described by Scott and Sumpter (1983).

\section{PRL mRNA measurement}

PRL mRNA concentrations were determined by slot blot hybridization as described by Cheley and Anderson (1984). Total RNAs were extracted from pituitary tissues according to Auffrey and Rougeon (1980). Hybridization was performed under high stringency conditions (Thomas, 1980) using rainbow trout PRL cDNA (Mercier et al., 1989). The nylon membrane (BiodynPall) was then stripped and reprobed for $\beta$-actin mRNA using rainbow trout cDNA (Pakdel et al., 1989). The autoradiographs were quantified by densitometric scanning. Results are expressed as arbitrary units of $\mathrm{PRL} /$ actin mRNA ratios.

\section{Statistical analysis}

Plasma PRL concentrations were analyzed by twoway analysis of variance. Differences between the controls and each of the treated groups for pituitary PRL and PRL mRNA measurements were analyzed by the Mann-Witney U-test. Differences among treatment groups and their respective controls were considered significant if $P<0.05$.

\section{Northern blot analysis}

Total RNA was extracted (Auffrey and Rougeon, 1980) from different pituitary parts: the rostral part (RPD) and proximal part (PPD) of the adenohypophysis pars intermedia (PI). Poly $(A)^{+}$RNAs, obtained 
after chromatography of the total RNA on oligo(dT)trisacryl $\mathrm{M}$, were separated on $1 \%$ agarose gel and transferred to a nylon membrane (Biodyn-Pall). Hybridization was performed with a ${ }^{32} \mathrm{P}$-labeled complete rtER cDNA under Thomas' conditions (1980). Trout pro-opiomelanocortin (POMC) (Salbert et al., 1992) and rtER (Pakdel et al., 1989) cDNAs were cloned in our laboratory. Full-length rtER cDNA as well as two different restriction fragments, PstI-PstI encoding the $\mathrm{C}$ and $\mathrm{D}$ domains and Apal-Apal encoding $\mathrm{E}$ domain of rtER, were used in hybridization experiments.

\section{In situ hybridization analysis}

The in situ hybridization protocol has been described by Salbert et al. (1991). Briefly, anesthetized trout were intracardially perfused with $4 \%$ paraformaldehyde in phosphate-buffered saline (PBS). Pituitaries were removed and fixed overnight. After inclusion in paraffin wax, serial $6 \mu \mathrm{m}$ sections were cut and submitted to the in situ hybridization protocol. Each slide was covered with $2.66 \mathrm{ng}$ of $\left.{ }^{35} \mathrm{~S}\right]$ UTP-labeled probe $(1.5 \mathrm{X}$ $\left.10^{9} \mathrm{cpm} / \mu \mathrm{g}\right)$ in $20 \mu \mathrm{l}$ of hybridization buffer. This concentration has been demonstrated to be saturating (Salbert et al., 1991). Hybridization was carried out overnight and sections were then washed, dehydrated and autoradiographed for 10 days. The probe was a 350 base-long complementary RNA synthesized from a fragment of the estrogen binding domain of the rtER cDNA.

Grain counting. Silver grains were counted over cells of different regions of the pituitary. Prolactin cells were easily localized by their follicular organization in the RPD. Thirteen prolactin cells were randomly chosen for grain counting in three animals per group (immature trout and mature female trout at the end of vitellogenesis). Thirteen cells in the PI and PPD were randomly chosen for grain counting among cells where labcling was at lcast 3 times over background. Background was estimated by grain counting over 40 pituitary cells per animal hybridized with the sense probe and was subtracted from the specific signal.

\section{Results}

\section{Effects of in vivo estradiol treatment in mature and immature rainbow trout}

Single injections of peanut oil-containing estradiol at two different doses $(1$ or $10 \mu \mathrm{g} / \mathrm{g}$ ) increased plasma stcroid levels in immature rainbow trout. The low dose induced an acute increase in steroid levels that retumed to basal within 3-4 days, whereas the higher dose resulted in a more sustained increase over a 7-day period (Fig. 1). Both treatments did not result in any significant changes in plasma PRL levels (Fig. 1). Estradiol treatment ( $5 \mu \mathrm{g} / \mathrm{g}$ body weight) applied in immature fish using the same technique did not result

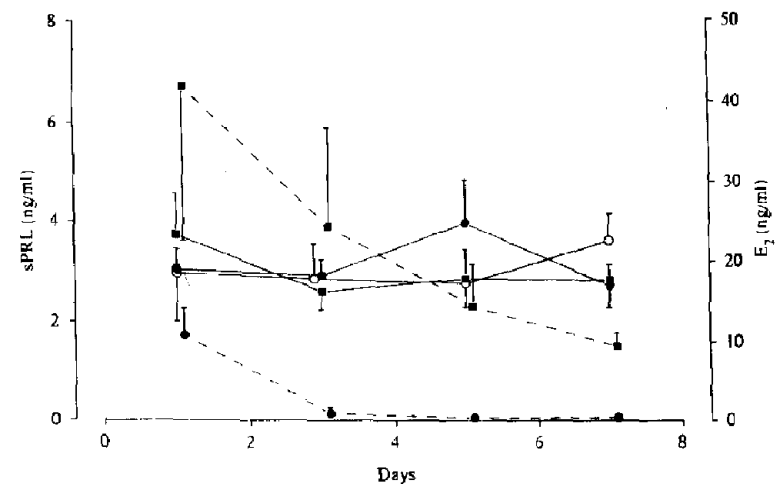

Fig. 1. Plasma PRL (— from day 0 to day 7 in immature rainbow trout treated with vehicle $(0), 1(\bullet)$ or $10(-) \mu \mathrm{g} / \mathrm{g} \mathrm{E}_{2}$ suspended in cacao butter. $E_{2}$ levels in control fish were not detectable at all times and are not shown. Values are given as mean $\pm \operatorname{SEM}(n=8), \mathrm{E}_{2}$ treatments did not induce a significant change in plasma PRL levels.

in a significant increase in both PRL mRNA level and pituitary content after 3 days of treatment (Fig. 2). Similarly, lack of estradiol effect on plasma PRL levels or on PRL pituitary content was observed in ovariectomized female rainbow trout receiving an $E_{2}$ implant (Fig. 3) and in mature male fish over a 3-week treatment period (data not shown).

\section{Localization of rtER mRNA in the pituitary by Northern blot analysis}

In rainbow trout pituitary, PRL cells are specifically localized in the RPD. After dissection of the different parts of the hypophysis (RPD, PPD and PI), rtER mRNA localization was studied in immature rainbow trout. Poly $(\mathrm{A})^{+}$prepared from the above tissues was analyzed by Northern blot using an rtER cDNA as a probe. Two mRNAs of 1.4 and $3.5 \mathrm{~kb}$ were observed in the pituitary. The $3.5 \mathrm{~kb}$ is similar to the trout liver ER mRNA whereas $1.4 \mathrm{~kb}$ mRNA is specific of the pituitary (Pakdel et al., 1990). The $3.5 \mathrm{~kb}$ species was more abundant in the PPD (Fig. 4, lane 2) while the $1.4 \mathrm{~kb}$ species was mostly located in the PI (Fig. 4, lane 3).
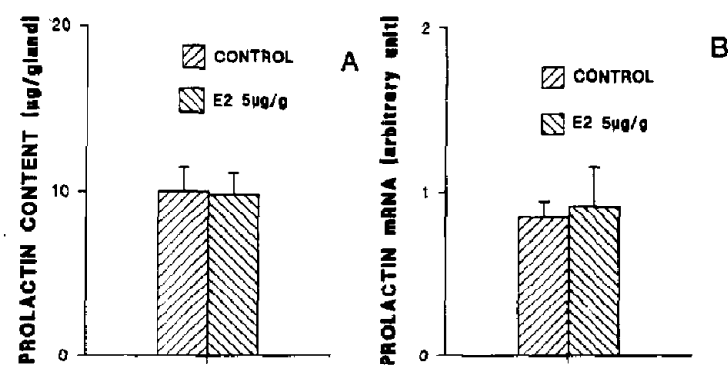

B

Fig. 2. Pituitary PRL content (in $\mu g /$ gland) and PRL/actin mRNA ratios (arbitrary units) in immature rainbow trout treated during 3 days with $E_{2}(5 \mu \mathrm{g} / \mathrm{g})$ suspended in cacao butter. Control fish were injected with the solvent. Values are given as mean $\pm \operatorname{SEM}(n=5)$. $\mathrm{E}_{2}$ did not produce a significant change in both pituitary PRL and PRL/actin mRNA ratios. 

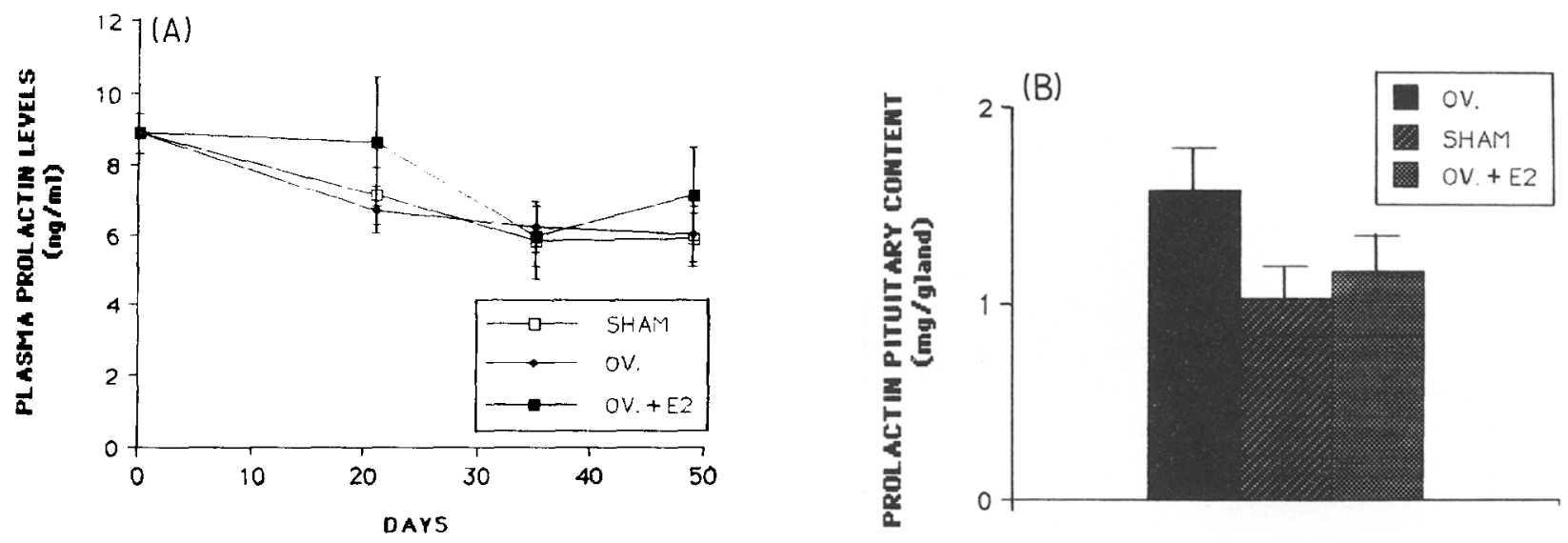

Fig. 3. Plasma PRL levels (in $\mathrm{ng} / \mathrm{ml}$, panel $A$ ) from day 0 to day 48 after surgery and pituitary PRL content (in $\mathrm{mg} / \mathrm{gland}$, panel $B$ ) at day 49 in adult female rainbow trout. Sham: sham-operated trout (control); $O V$ : ovariectomized fish; $O V+E_{2}$ : ovariectomized fish treated with $E_{2}$ implant $\left(5 \mu \mathrm{g} / \mathrm{g}\right.$ body weight). Results are expressed as mean $\pm \mathrm{SEM}(n=5) . \mathrm{E}_{2}$ treatment did not significantly change plasma PRL levels and pituitary PRL content.

The RPD contained lower but significant amounts of both mRNAs. In order to confirm the specificity of our dissection protocol, the above pituitary fragments were also analyzed after hybridization with different cellspecific cDNA probes (PRL, growth hormone (GH), POMC). Fig. 4 shows that these different parts were specifically enriched in one cell type: PRL cells in the RPD, GH cells in the PPD and POMC cells in the PI, although some cross-contamination remained apparent.

\section{Characterization of the two rtER mRNAs detected in the pituitary}

In order to further characterize the structure of the 3.5 and $1.4 \mathrm{~kb}$ rtER mRNAs, hybridization of poly-
(A) ${ }^{+}$RNA from trout pituitary was performed using two different rtER cDNA restriction fragments as probes. Fig. $5 A$ shows that 3.5 and $1.4 \mathrm{~kb}$ mRNAs can be detected in the pituitary when using a probe which contains only C (DNA binding domain) and D domains. However, a probe containing only $E$ domain (hormone binding domain) hybridized only with the 3.5 kb mRN $\Lambda$ (Fig. 5B).

Localization in the pituitary of estradiol receptor $m R N A$ by in situ hybridization analysis

In order to have a more precise picture of rtER mRNA localization, pituitary sections from immature and mature female rainbow trout were submitted to in situ hybridization using a probe synthesized from a

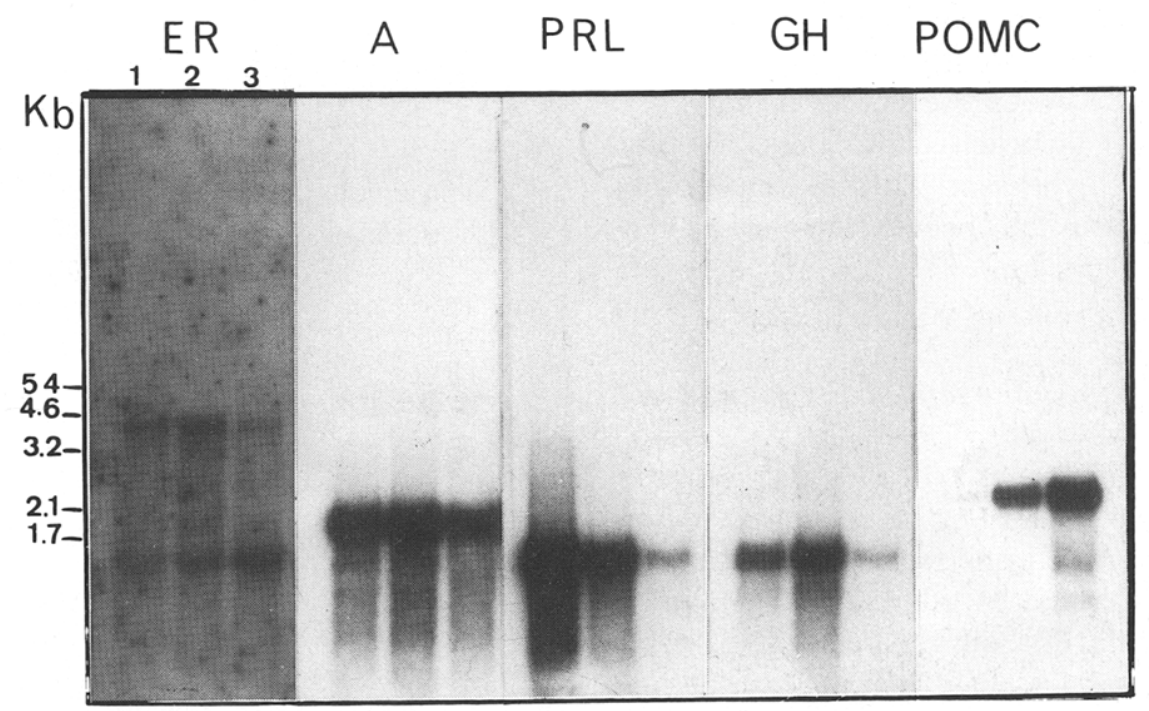

Fig. 4. Northern blot analysis of mRNA extracted from the different parts of the rainbow trout pituitary. $5 \mu \mathrm{g}$ of poly(A) ${ }^{+}$RNAs extracted from RPD (left lane), PPD (middle lane) or PI (right lane) were denaturated, electrophoresed and transferred to nylon membrane. The filter was successively hybridized with rainhow trout-specific cDNA probes (ER, estrogen receptor; A, actin; RPI, prolactin; GH, growth hormone; POMC, pro-opiomelanocortin-1. Exposure times were: ER, 60 h; A, 4 h; PRL, $5 \mathrm{~min}$; GH, $60 \mathrm{~min}$; POMC-1, $60 \mathrm{~min}$ ). 


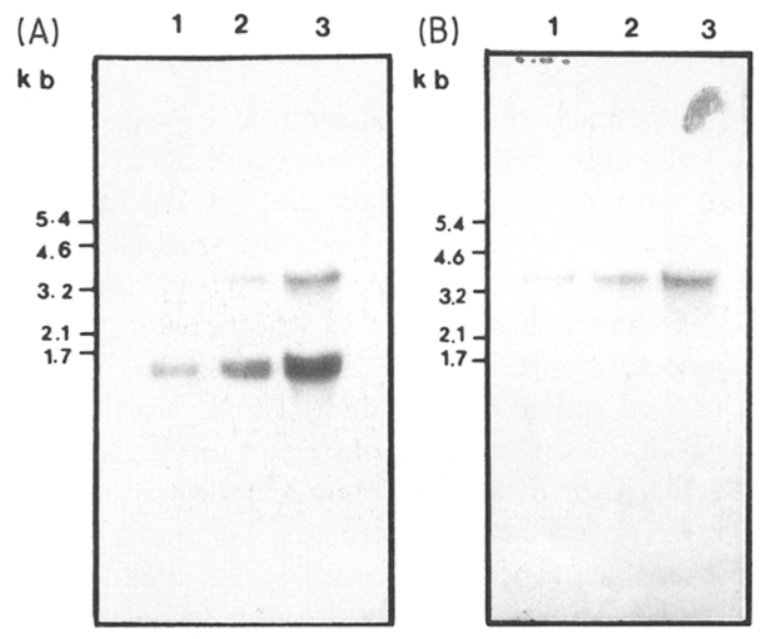

Fig. 5. Northern blot analysis of mRNAs extracted from rainbow trout pituitary. $4.25 \mu \mathrm{g}$ (lane 1), $8.5 \mu \mathrm{g}$ (lane 2) and $17 \mu \mathrm{g}$ (lane 3) of poly(A) ${ }^{+}$RNA were denaturated, electrophoresed and transferred to nylon membrane. The filter was successively hybridized with two different restriction fragments from rainbow trout ER cDNA (panel $A$, Apal-Apal fragment corresponding to the $\mathrm{E}$ domain; panel $B$, PstI-Pstl fragment corresponding to the $C$ and $D$ domains). Exposure time was 7 days at $-80^{\circ} \mathrm{C}$.

fragment of the hormone binding domain of the rtER cDNA. PRL cells can be easily identified only in the RPD part of the pituitary due to their typical follicular

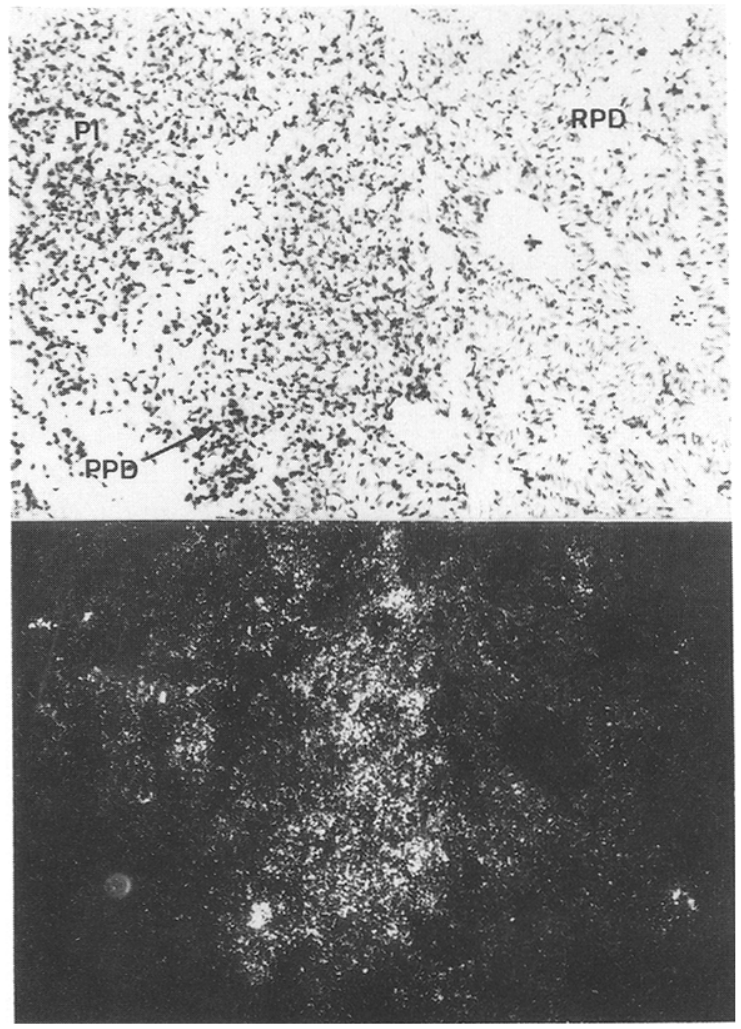

Fig. 6. Bright-field/dark-field photomicrographs of a pituitary $6 \mu \mathrm{m}$ section from a mature female rainbow trout. Hybridization was performed with the anti-sense rtER RNA. RPD, rostral pars distalis; PPD, proximal pars distalis; PI, pars intermedia.

\section{IMMATURES}

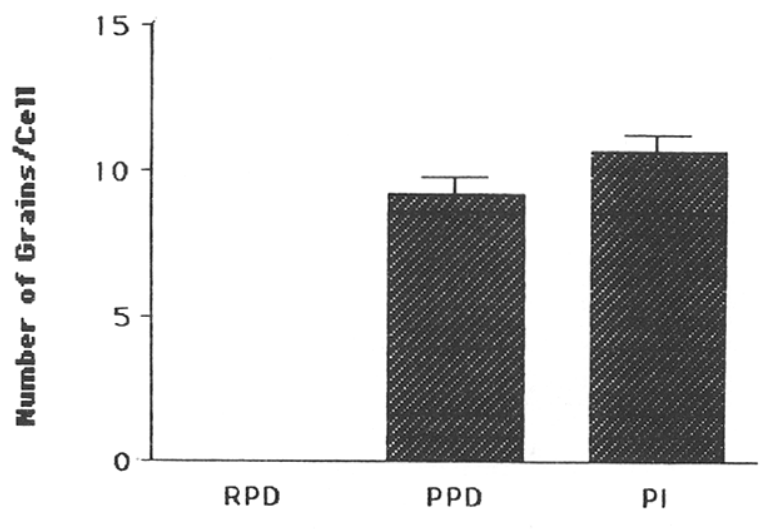

MATURES

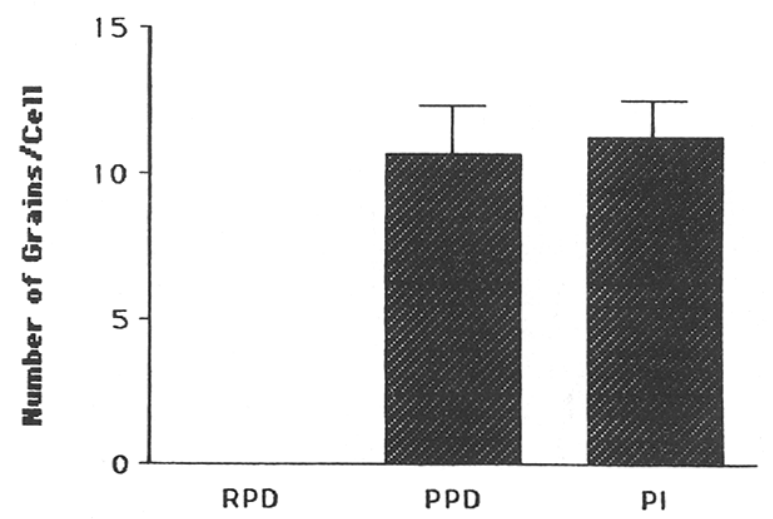

Fig. 7. Intensity of the specific signal observed over different cell types in the pituitary. Results are shown as mean \pm SEM $(n=3)$ for immature trout or mature female trout. RPD, prolactin cells of the rostral pars distalis; PPD, labeled cells of the proximal pars distalis, PI, labeled cells of the pars intermedia. No specific signal was detected in the RPD cells.

arrangement. Fig. 6 shows that the labeling over PRL cells in the RPD was indiscernible from the background whereas almost all cells of the PPD and some cells in the PI were labeled. Grain counting corroborated these observations as no specific signal could be detected over PRL cells in pituitaries from either immature or mature animals (Fig. 7). Even if labeled cells in the PI were more sparse than in the PPD, expression of the ER gene per cell seemed to be identical in these two parts of the pituitary.

\section{Discussion}

The present study clearly shows that in vivo application of $E_{2}$ treatment in rainbow trout neither modifies pituitary PRL and PRL mRNA contents nor induces changes in serum PRL concentration. The $E_{2}$ doses used in experiment 1 let to an increase in plasma $E_{2}$ levels which were in the normal range of $E_{2}$ values measured during vitellogenesis in female trout (Fostier 
et al., 1983). The effectiveness of these treatments was further demonstrated by an increase in total plasma calcium levels (data not shown), an effect previously observed in rainbow trout (Bjornsson et al., 1989). The use in experiment 2 of a similar implant technique and of an intermediate $E_{2}$ dose would probably also have led to an increase in plasma $E_{2}$ levels.

The use of silastic pellets mixed with $E_{2}$ (experiment 3) is a well-known technique to obtain, in fish, a long-term elevation in plasma $E_{2}$ levels (Pankhurst et al., 1986). Previous experiments realized in our laboratory in adult triploid rainbow trout have shown that estradiol administered in silastic pellets $(2 \mu \mathrm{g} / \mathrm{g}$ body weight) produced a large elevation in plasma $E_{2}$ levels which stayed above $20 \mathrm{ng} / \mathrm{ml}$ for more than 4 weeks (Breton, B., personal communication).

In experiment 4 on ovariectomized fish, plasma $E_{2}$ levels were analyzed over the whole treatment period (Saligaut et al., 1992): the results indicated a large increase in plasma $E_{2}$ levels $>8 \mathrm{ng} / \mathrm{ml}$; moreover, $\mathrm{GtH}$ pituitary content measured at the end of the treatment was significantly increased, thus confirming the efficiency of steroid stimulation (Crim et al., 1981). However, this treatment did not induce any change in PRL pituitary content although $\mathrm{E}_{2}$ plasma levels in the treated fish fell within physiological values (8-12 $\mathrm{ng} / \mathrm{ml}$ ) usually observed in rainbow trout between vitellogenesis and maturation (Saligaut et al., 1991). Thus, the absence of $E_{2}$ effects on PRL in our study cannot be explained by an insufficient plasma $E_{2}$ increase in the treated fish.

In order to obtain a more complete picture of PRL cell regulation by estrogen, rainbow trout at different stages of maturation have been used in this study. In all our experiments on immature fish, male mature or female ovariectomized fish, $E_{2}$ supplementation exerted no effect. This is clearly different from what has been suggested in another fish species, the eel, in which $\mathrm{E}_{2}$ stimulated PRL cells in adult males and females (Olivereau and Olivereau, 1979; Olivereau et al., 1986). Moreover, using pituitaries from adult male tilapia, Barry and Grau (1986) have also observed a stimulation of PRL released after in vitro $E_{2}$ treatment.

In mammals numerous publications have dealt with the influence of $E_{2}$ on PRL secretion (see Fink, 1988). Estrogen treatment stimulates both pituitary PRL content and plasma PRL levels in mature male or female rats (Nogami, 1984) and in ovariectomized female rats (Chen and Meites, 1970). In addition, $\mathrm{E}_{2}$ also exerts effects on rat PRL gene transcription with a stimulation of PRL mRNA synthesis in the adult rat (Maurer, 1982; Yamamoto et al., 1986). No such effects were observed in the present study, in which $\mathrm{E}_{2}$ did not modify the various PRL parameters analyzed in mature or immature rainbow trout: our results then suggest a lack of regulation of PRL cells by estrogens in this fish species.

In mammals, the regulatory role of estrogens on PRL cells appeared to be exerted directly at the level of the anterior pituitary gland and by modulation of the action of hypothalamic releasing factors. In order to further investigate which level of regulation could differ in the rainbow trout and whether PRL cells are targets for estrogen, the localization of ER synthesis was carried out in the pituitary gland. Northern blot analysis in the different pituitary parts using full-length rtER cDNA for hybridization indicated the presence of two mRNAs of different size $(3.5 \mathrm{~kb}$ and $1.4 \mathrm{~kb})$, in agreement with previous results from Pakdel et al. (1990). $1.4 \mathrm{~kb}$ mRNA hybridized with a restriction fragment encoding rtER DNA binding domain but not with a restriction fragment encoding the hormone binding domain of rtER. This indicates that the $1.4 \mathrm{~kb}$ mRNA encodes either a truncated form of rtER lacking the hormone binding domain or a related protein. Thus, in rainbow trout, regulation of pituitary function by estradiol is more likely to be associated with the 3.5 $\mathrm{kb}$ mRNA which has been shown to encode a functional ER protein in trout liver (Pakdel et al., 1990). 'I he $1.4 \mathrm{~kb}$ mRNA appeared to be dominant in the Pl whereas in the RPD and PPD the amounts of $1.4 \mathrm{~kb}$ and $3.5 \mathrm{~kb}$ mRNAs were equal. Both signals were found with a lower intensity in the RPD (in which all PRL cells are located) compared to the two other pituitary parts. This may suggest a lower expression level of the FR gene in PRL cells. However, it is also possible to explain these results by contamination of RPD by PPD cells (mostly gonadotrophs, somatotrophs and thyreotrophs) and by PI cells as our dissection protocol cannot provide a pure PRL cell population. This is clearly indicated by Northern blot analysis of each pituitary fragment using $\mathrm{GH}$ and POMC- 1 cDNA as probes (Fig. 5): RPD appeared to contain a significant amount of GH mRNA but a much lower amount of POMC-1 originating from PI. Interestingly, the yield of the GH signal in RPD versus PPD is of the same order of magnitude as the yield of each rtER signal ( 3.5 and $1.4 \mathrm{~kb}$ ) in RPD versus PPD. This suggests that the presence of these two mRNAs in the RPD fragments would be due to contamination with material from PPD and not to the expression of the ER gene in PRL cells.

In situ hybridization studies using a short labeled RNA probe which hybridized only with $3.5 \mathrm{~kb}$ rtER mRNA allows precise localization of pituitary cells expressing ER: it confirms that 3.5 ER mRNA is not detected in PRL cells but is mostly present in the PPD and PI cells. These studies were conducted both in immature and mature female rainbow trout in which we have previously shown that in vivo $E_{2}$ treatment did not modify PRL function. Interestingly, comparison 
between immature and mature female rainbow trout showed no increase in the number of grains per PPD or PI cells suggesting that expression of the ER gene in the pituitary is not strongly regulated by $E_{2}$. This is clearly different from what has been shown in trout liver by Pakdel et al. (1991). Different regulation of rtER mRNA levels according to the cell type in the brain and in the pituitary of rainbow trout has been suggested by Salbert et al. (1991). The above in situ hybridization results confirm the absence or undetectable amount of functional ER in the PRL cells of rainbow trout. A similar situation has also been described in catfish in which immunocytochemical studies localized $\mathrm{E}_{2}$ mainly in gonadotroph cells while no significant signal was observed in PRL cells (Peute et al., 1989).

In conclusion, in vivo estradiol treatment which does not modify PRL cell activity and the absence of $3.5 \mathrm{~kb}$ rtER mRNA in the PRL cells confirm that these cells are not a target for estrogens and that PRL secretion in the trout species is not directly regulated by estradiol. This situation appears to be different to what has been observed in other fish species (see Introduction): such diversity in the neuroendocrine control of PRL secretion is not rare and has already been suggested for the role of osmotic pressure or for hypothalamic control of PRL secretion (Nishioka et al., 1988).

Experiments are presently in progress to determine the implication of such an absence or estrogen regulation for the structure of the PRL gene promoter and particularly the presence or absence of a functional estrogen responsive element (ERE) consensus sequence.

\section{Acknowledgements}

The authors thank Prof. J. Duval for helpful criticism of the manuscript and Mrs. T. Perrier for typing it. This work was supported by a grant from 'Region Bretagne' (BRITTA program) to I.N.R.A.

\section{References}

Auffrey, C. and Rougeon, F. (1980) Eur. J. Biochem. 107, 303-314. Barry, T.P. and Grau, E.G. (1986) Gen. Comp. Endocrinol. 62, 306-314.

Bjornsson, B.Th., Haux, C., Bern, H.A. and Deftos, L.J. (1989) Endocrinology 125, 1754-1760.

Bommelaer, M.L., Billard, R. and Breton, B. (1981) Reprod. Nutr. Dev. 21, 989-997.

Cheley, S. and Anderson, R. (1984) Anal. Biochem. 137, 15-19.

Chen, C.L. and Meites, J. (1970) Endocrinology 92, 1256-1268.

Conneely, O.M., Dorson, A.D.W., Tsai, M.J., Beattie, W.G., Toft, D.O., Huckaby, C.S., Tarvki, T., Schrader, W.T. and O'Malley, B.W. (1987) Mol. Endocrinol. 1, 517-525.

Crim, L.W., Peter, R.E. and Billard, R. (1981) Gen. Comp. Endocrinol. 44, 374-381.

De Lean, A., Ferland, L., Drouin, J., Kelly, P.A. and Labrie, F. (1977) Endocrinology 100, 1496-1504.
Ellerkman, E., Nagy, G.M. and Frawley, L.S. (1991) Endocrinology $129,838-842$.

Fink, G. (1988) J. Steroid Biochem. 30(1-6), 169-178.

Fostier, A., Jalabert, B., Billard, R., Breton, B. and Zohar, Y. (1983) in Fish Physiology (Hoor, W.S., Randall, D.J. and Donaldson, E.M., eds.), Vol. 9, Part A, pp. 277-372 (Academic Press, New York).

Hillier, S.G., Saunders, P.T.K., White, R. and Parker, M.G. (1989) J. Mol. Endocrinol. 2, 39-45.

Kalra, P.S., Fawcett, C.P., Krulich, L. and McCann, S.M. (1973) Endocrinology 92, 1256-1258.

Keffer, D.A. (1981) J. Histochem. Cytochem. 29, 167-174.

Keffer, D.A., Stumpf, W.E. and Petrusz, P. (1976) Cell Tissue Res. $166,25-35$.

Krust, A., Green, S., Argos, P., Kumar, V., Walter, P., Bornert, J.M. and Chambon, P. (1986) EMBO J. 5, 891-897.

Lieberman, M.E., Maurer, R.A., Claude, P. and Gorski, J. (1982) Mol. Cell. Endocrinol. 25, 277-294.

Maurer, R.A. (1982) J. Biol. Chem. 257, 2133-2136.

Mercier, L., Rentier-Delrue, F., Swennen, D., Lion, M., Le Goff, P., Prunet, P. and Martial, J.A. (1989) DNA 8, 119-125.

Nagahama, Y., Nishioka, R.S., Bern, H.A. and Gunther, R.L. (1975) Gen. Comp. Endocrinol. 25, 166-188.

Nishioka, R.S., Kelley, K.M. and Bern, H.A. (1988) Zool. Sci. 5 , 267-280.

Nogami, H. (1984) Cell Tissue Res. 237, 195-202.

Nogami, H., Herbert, D.C., Winborn, W.B., Weader, F.J. and Sheridan, P.J. (1987) Cell Tissue Res. 248, 75-78.

Olivereau, M. and Olivereau, J. (1979) Cell Tissue Res. 199, 431-454.

Olivereau, M., Dubourg, P., Chambolle, P. and Olivereau, J. (1986) Cell Tissue Res. 246, 425-437.

Pakdel, F., Le Guellec, C., Vaillant, C., Le Roux, M.G. and Valotaire, Y. (1989) Mol. Endocrinol. 3, 44-51.

Pakdel, F., Le Gac, F., Le Goff, P. and Valotaire, Y. (1990) Mol. Cell. Endocrinol. 71, 195-204.

Pakdel, F., Feon, S., Le Gac, F., Le Menn, F. and Valotaire, Y. (1991) Mol. Cell. Endocrinol. 75, 205-212.

Pankhurst, N.W., Stacey, N.E. and Peter, R.E. (1986) Aquaculture 52, 145-155.

Pasqualini, C., Bofda, F. and Kerdelhue, B. (1986) Endocrinology $119,2484-2489$.

Peute, J., Schulz, R., Glazenburg, K., Lambert, J.G.D. and Blum, V. (1989) Gen. Comp. Endocrinol. 76, 63-72.

Prunet, P., Boeuf, G. and Houdebine, L.M. (1985) J. Exp. Zool. 235, $187-196$.

Rentier-Delrue, F., Swennen, D., Mercier, L., Lion, M., Benrubi, O. and Martial, J.A. (1989) DNA 8, 109-117.

Salbert, G., Bonnec, G., Le Goff, P., Boujard, D., Valotaire, Y. and Jego, P. (1991) Mol. Cell. Endocrinol. 76, 173-180.

Salbert, G., Chauveau, I., Bonnec, G., Valotaire, Y. and Jego, P. (1992) Mol. Endocrinol. (in press).

Saligaut, C., Garnier, D.-H., Bennani, S., Salbert, G., Bailhache, T. and Jego, P. (1992) Gen. Comp. Endocrinol. (in press).

Scott, A.P. and Sumpter, J.P. (1983) Gen. Comp. Endocrinol. 52, $79-85$.

Shin, S.H., Aiken, R.B., Roberts, R. and Howitt, C. (1974) J. Endocrinol. 63, 257-258.

Takahashi, S. and Kawashima, S. (1987) Zool. Sci. 4, 855-860.

Thomas, P.S. (1980) Proc. Natl. Acad. Sci. USA 77, 5201-5205.

White, B.A. and Bancroft, F.C. (1982) J. Biol. Chem. 257, 8569-8572.

Wigham, T., Nishioka, R.S. and Bern, H.A. (1977) Gen. Comp. Endocrinol. 32, 120-131.

Yamamoto, N., Sed, H., Suganuma, N., Matsui, N., Nakane, T., Kuwayama, A. and Kageyama, N. (1986) Neuroendocrinology 42, 494-497.

Zhang, J., Chen, C., Kukstas, L.A., Verrier, D., Vincent, I.D. and Israel, J.M. (1990) J. Neuroendocrinol. 2(3), 277-284. 